\title{
ESTIMATION OF CALCIUM REQUIREMENT OF GROWING YANKASA LAMBS BY FACTORIAL METHOD
}

\author{
OKOYE, F.C. \\ College of Education, Awka \\ N.N. UMUNNA \\ Animal Science Department, \\ Ahmadu Bello University, \\ Zaria. \\ C.N. CHINEME \\ Department of Veterinary Pathology, \\ University of Nigeria, \\ Nsukka.
}

(Received 10 October 1988; accepted for publikation 11 March 1989)

\section{ABSTRACT}

Fifty-two Yankasa lambs of mixed sexes age, 6 to 8 months, were used in this study to determine calcium requirement. Varying levels of dietary calcium viz: 0.28 , $0.42,0.56,0.70,0.86,0.99$ and $1.15 \%$ were tested in a completely randomized design. Phosphorus was kept constant at the level in the control ration. The criteria of adequacy employed included clinical observations, growth performance and mineral retention. No clinical abnormality was observed among the groups throughout the experimental period. Although growth performance improved with increase in dietary calcium level, treatment effects among groups on $0.70,0.86,0.99$ and $1.15 \%$ dietary levels were not significant $(P>0.05)$. Apparent dry matter digestibility and calcium retention improved with increase in dietary calcium. Mean calcium requirement for lambs was $305 \mathrm{mg} /$ day $/ \mathrm{kg}$ body weight. Comparisons with the findings of some temperate workers showed that while the endogenous calcium loss for lambs in this region was lower, their requirement for calcium was higher than those in the temperate region.

Key Words: Dietary calcium, Yankasa lambs.

\section{INTRODUCTION}

The productivity of indigenous livestock in Nigeria is low. Part of the constraints to increased productivity of these animals include inherent low genetic capacity (Shaw and Colville, 1950), poor marketing system, prevalence of numerous diseases (Adegbola, 1971), low plane of nutrition and low quality feed (Oyenuga, 1958; Lansbiury, 1960). Most of the sheep are grazed on limited pastureland and this coupled with the low quality of 
the forage aggravates the poor nutritional status of the sheep. Thus, efforts at improving animal production in Nigeria should give considerable attention to the nutrition of the animals (Miller, 1961; F.A.O., 1966)

Calcium is one of the most important mineral nutrients required by all farm animals. Apart from its physiological functions, studies (Burroughs, et. al., 1950 and Varner and Woods, 1972) have shown that calcium is involved in bacterial metabolism in the rumen, which enhances digestibility of fibre and organic matter. Inadequacy of dietary calcium would have adverse effect on utilization of other mineral like phosphorus.

There is paucity of information on calcium requirements of Nigerian sheep, Stock owners seem to rely on results obtained for temperate sheep. This must not be taken for granted since livestock requirements could be influenced by climate, breed and specie. The present study was therefore conducted to determine the calcium requirement of growing Yankasa lambs.

\section{MATERIALS AND METHODS}

Fifty-two Yankasa lambs of mixed sexes were used in a 70-day feeding trial to determine their calcium requirement in savanna region of Nigeria. The lambs, aged 6 to 8 months, were bought locally from markets around Zaria, quarantined and conditioned for four weeks during which they were dewormed bi-weekly until certified free from intestinal parasite. The first trial was carried out with twenty animals, which were assigned to four levels of dietary calcium, viz; $0.28,0.42,0.56$ and $0.70 \%$, so that there were five animals per treatment. The second trial was conducted with thirty-two animals, which were assigned four levels of dietary calcium viz, $0.70,0.86,0.99$ and $1.15 \%$ respectively, with eight animals per treatment. Phosphorus was kept constant at the level in the control ration $(0.31 \%)$.
At the end of the study, a balance trial was conducted. Twenty-one young ram lambs, aged between 6 and 9 months, were purchased from local markets around Zaria, quarantined and dewormed as in the growth study. The animals were fed experimental diet used in the growth study for a preliminary period of 21 days. On day 17, each animal was fitted with a faecal collection harness and placed in a metabolism cage for an adjustment period of four days. The three-week preliminary period was immediately followed by a 7-day total faecal and urine collection period. Urine was collected in plastic buckets, containing $100 \mathrm{~m}$ of $50 \% \mathrm{HCL}$. This balance trial was replicated thrice to give a total at 3-7-day collection period. Forty percent of the total dry matter (gm) intake per day was provided by hay (Andropogon sp.) while the remaining 60\% was supplied by the supplements (Table 1). Vitamin D was incorporated in the supplement to supply at least 5.6 i.u. per $\mathrm{kg}$ live weight per day (NRC, 1975). The calcium content of the basal ration $(0.28 \%$ ) was varied by the addition of calcium carbonate, (Table 1). The hay and supplements were weighed out separately and offered to each animal at above 0800 hours daily. Feed was adjusted every other day in an attempt to maintain the adopted ratio of hay to concentrate. Any feed refusal was weighed to assess intake. In the feeding studies, lambs were weighed at the beginning of the experiment and thereafter at two-weekly intervals.

The daily faecal output from each animal in the balance trial was collected, weighed and stored in polythene bags at $-15^{\circ} \mathrm{C}$. The daily urine output from each animal was measured and a $10 \%$ sample was taken and stored at $-15^{\circ} \mathrm{C}$ in plastic bottles. Samples of hay, feed and feed refusals were collected and stored for analysis. 
Table 1

Composition (\%) of Supplements Fed in the Experiment

\begin{tabular}{|c|c|c|c|c|c|c|c|}
\hline Item & 1 & 2 & 3 & 4 & 5 & 6 & 7 \\
\hline $\begin{array}{l}\text { Calcium } \\
\text { in diet } \\
\text { Phosphorus }\end{array}$ & 0.28 & 0.42 & 0.56 & 0.70 & 0.86 & 0.99 & 1.15 \\
\hline in diet & 0.31 & 0.31 & 0.31 & 0.31 & 0.31 & 0.31 & 0.31 \\
\hline $\begin{array}{l}\text { Common Salt } \\
\text { Vitamin/ }\end{array}$ & 0.7 & 0.7 & 0.7 & 0.7 & 0.7 & 0.7 & \\
\hline $\begin{array}{l}\text { Mineral } \\
\text { Premix }^{2}\end{array}$ & $\begin{array}{l}0.06 \\
0.0125\end{array}$ & $\begin{array}{l}0.06 \\
0.0125\end{array}$ & $\begin{array}{l}0.06 \\
0.0125\end{array}$ & $\begin{array}{l}0.06 \\
0.0125\end{array}$ & $\begin{array}{l}0.06 \\
0.0125\end{array}$ & $\begin{array}{l}0.06 \\
0.0125\end{array}$ & 0.06 \\
\hline $\begin{array}{l}\text { Maize } \\
\text { Groundnut }\end{array}$ & 72.54 & 71.73 & 70.99 & 70.23 & 68.97 & 70.84 & 70.36 \\
\hline $\begin{array}{l}\text { cake } \\
\text { Calcium }\end{array}$ & 26.71 & 26.97 & 27.13 & 27.30 & 27.48 & 25.50 & 25.33 \\
\hline Carbonate & - & 0.55 & 1.13 & 1.72 & 2.30 & 2.90 & 3.55 \\
\hline \multicolumn{8}{|c|}{$\begin{array}{l}\text { Analyzed Chemical Composition } \\
\text { Crude }\end{array}$} \\
\hline protein (\%) & 21.4 & 21.3 & 20.5 & 20.5 & 19.70 & 20.1 & 20.5 \\
\hline Calcium (\%) & 0.34 & 0.41 & 0.56 & 0.67 & 0.83 & 0.94 & 1.07 \\
\hline Phosphorus (\%) & 0.38 & 0.35 & 0.33 & 0.39 & 0.31 & 0.30 & 0.29 \\
\hline Ca:P/Ratio & 1:1 & $1: 1$ & $1.7: 1$ & $1.7: 1$ & $2.7: 1$ & $3: 1$ & $3.7: 1$ \\
\hline
\end{tabular}

a

Composition of premix per 1000g: Vitamin A, 7,500,000 1.U.: Vitamin D3, 1,500,000 I.U.; Vitamin B1, $1000 \mathrm{mg}$; Vitamin B12, 5mg; D-Calcium pantothenate $5000 \mathrm{mg}$; Vitamin E, 2500mg; Ethoxyquin, 5000mg; Manganese oxide, $16.130 \mathrm{mg}$; potyassium iodide, 353mg; cobalt sulphate, 286mg; zinc oxice, 12,500mg; Copper ocide, 1,283mg, Ferrocarbonate, 20,323mg; Milocorn ad. 1000g. 
The calcium and magnesium contents of the faeces, urine, feed samples and refusals were determined by wet digesiion using atomic absorption spectrophotometer (Willis, 1960, 1961). Phosphorus in digested samples of faeces, urine, feed and refusals was determizid by molybdovanadate method (Fiske and Subbarow 1925) as outlined Hawk, et. al. 1967).

Growth and balance data were subjected to analysis of variance and treatment means where significant, were compared using Duncan's Multiple Range Test (Steel and Torrie, 1960).

\section{RESULTS}

The animals appeared clinically healthy and there were no cases of feed rejection, still gait, arched back or lameness. Growth data are presented in Table 2 . Treatment effects on rate of gain feed intake and feed efficiency were significant $(\mathrm{P}<.05)$. Weight gains and feed efficiency improved with increasing levels of dietary calcium. However, there were no differences in growth rate recorded for lambs on $0.70,0.86,0.99$ and $1.15 \%$ dietary calcium. Information on balance trials is summarísed in Table 3. Apparent dry matter digestibility increased $(P<0.05)$ with increases in levels of dietary calcium. Higher values were obtained for animals on the two highest dietary calcium levels $(0.99$ and $1.15 \%$ ). These two were similar but significantly higher $(P<0.05)$ than corresponding values for those on other groups. Treatment effects on faecal and urinary excretion of calcium were also significant $(P<.05)$. Faecal and urinary excretion of calcium increased with increase in calcium intake. There were linear relationships between caintake and (i) Faecal-Calg/day) (ii) urinaryCalg/day). The relationships are described by:

$$
\mathbf{Y}=0.094+0.33 \times(\mathbf{r}=0.995)
$$

where
$\mathrm{X}=$
$\mathrm{Y}=$
$\mathrm{Ca}$ - intake (g/day); and,
$\mathrm{Y}=$ faecal ca-excretion ( $g /$ day) and
where
$\mathrm{X}=$ Ca-intake (g/day); and,
$\mathrm{Y}=\quad$ Urinary-Ca excretion ( $\mathrm{g} /$ day)

The correlation coefficients (r) were highly significant $(\mathrm{P}<0.01)$. The equations show that at zero intake, the total faecal excretion of calcium would be $94 \mathrm{mg} /$ day while total calcium loss in urine would be $10 \mathrm{mg} /$ day. The total endogenous loss of calcium for each lamb was therefore $108 \mathrm{mg}$ /day or $5.5 \mathrm{mg} / \mathrm{kg}$ body weight per day. Calcium retained, as estimated from the balance data are shown in Table 3. From equations (i) and (ii), when ca-intake (x) is hypothetically zero, the values of $Y$ give the metabolic faecal ca and endogenous urinary ca. These values ( $\mathrm{mg} /$ day) were 94 and 10 for faecal and urinary $\mathrm{ca}$ is respectively.

Retention was influenced by the level of calcium intake and increased with increases in calcium intake. Significant differences $(\mathbf{P}<0.001)$ existed among groups for calcium retention.

\section{DISCUSSION}

Calculation of the mineral requirement of farm animals is based on information on endogenous losses, body storage and availability. The value of $5.5 \mathrm{mg}$ per $\mathrm{kg}$ body weight obtained for endogenous calcium in this experiment is markedly lower than the values reported by most temperate workers. These values range from $8 \mathrm{mg} / \mathrm{kg}$ body weight per day by Hodge (1973) to $60 \mathrm{mg} / \mathrm{kg}$ body weight by Tillman and Brethour (1958). Lucker and Lofgreen (1961) suggested that metabolic faecal calcium does not vary with ca-intake. Although the physiological significance of endogenous faecal ca ha: not been thoroughly resolved, 
Table 2

Growth Performance of Lambs Fed Different Calcium Levels in the Diets

TREATMENT

\begin{tabular}{|c|c|c|c|c|c|c|c|c|c|}
\hline & 1 & 2 & 3 & 4 & 5 & 6 & 7 & $\begin{array}{l}\text { Grand } \\
\text { Mean }\end{array}$ & S.E. ${ }^{1}$ \\
\hline $\begin{array}{l}\text { Ca. } \\
\text { content } \\
\text { of diet } \\
(\%)\end{array}$ & 0.28 & 0.42 & 0.56 & 0.70 & 0.86 & 0.99 & 1.15 & & \\
\hline $\begin{array}{l}\text { P. } \\
\text { content } \\
\text { of diet } \\
(\%)\end{array}$ & 0.38 & 0.35 & 0.33 & 0.39 & 0.31 & 0.30 & 0.29 & & \\
\hline $\begin{array}{l}\text { Av. } \\
\text { initial } \\
\text { weight } \\
(\mathrm{kg})\end{array}$ & 14.3 & 14.4 & 15.1 & 18.3 & 17.4 & 17.1 & 17.0 & 16.23 & \\
\hline $\begin{array}{l}\text { Av. } \\
\text { final } \\
\text { weight } \\
(\%)\end{array}$ & 17.7 & 18.7 & 20.1 & 24.3 & 23.5 & 24.2 & 24.3 & 21.8 & \\
\hline $\begin{array}{l}\text { Av. } \\
\text { daily } \\
\text { gain } \\
\text { (g) }\end{array}$ & $35.5^{\mathrm{e}}$ & $51.0^{\mathrm{d}}$ & $58.8^{\mathrm{d}}$ & $70.6^{\mathrm{ab}}$ & $71.8^{\mathrm{ab}}$ & $83.9^{\mathrm{ab}}$ & $85.9^{\mathrm{ab}}$ & 65.9 & \pm 5.7 \\
\hline $\begin{array}{l}\text { Daily DM } \\
\text { feed } \\
\text { intake } \\
\text { (g) }\end{array}$ & $539.3^{\mathrm{e}}$ & $604.3^{d}$ & $635.8^{\mathrm{d}}$ & $685.9^{\mathrm{ab}}$ & $669.0^{\mathrm{b}}$ & $682.4^{b c}$ & $707.4^{\mathrm{ab}}$ & 646.2 & \pm 25.36 \\
\hline $\begin{array}{l}\text { Feed } \\
\text { efficiency } \\
\text { ( } \mathrm{g} \text { feed/ } \\
\text { g gain) }\end{array}$ & $13.7^{\mathrm{abc}}$ & $11.8^{\mathrm{ab}}$ & $10.8^{\mathrm{ab}}$ & $9.7^{b c}$ & $9.3^{b c}$ & $8.2^{\mathrm{d}}$ & $8.2^{\mathrm{d}}$ & 10.2 & \pm 0.36 \\
\hline
\end{tabular}


Table 3

\section{TREATMENT}

\begin{tabular}{|c|c|c|c|c|c|c|c|c|c|}
\hline & 1 & 2 & 3 & 4 & 5 & 6 & 7 & $\begin{array}{l}\text { Grand } \\
\text { Mean }\end{array}$ & s.E. ${ }^{1}$ \\
\hline $\begin{array}{l}\mathrm{DM} \\
\text { diges- } \\
\text { tibility } \\
(\%)\end{array}$ & $63.10^{d}$ & $65.20^{\mathrm{d}}$ & $68.80^{b c}$ & $73.40^{\mathrm{bc}}$ & $76.60^{\mathrm{ab}}$ & $77.20^{\mathrm{ab}}$ & 70.20 & \pm 0.56 & \\
\hline $\begin{array}{l}\text { Calcium } \\
\text { intake } \\
(\mathrm{g} / \mathrm{d})\end{array}$ & 1.82 & 2.64 & 3.57 & 4.60 & 5.60 & 6.40 & 7.50 & 4.59 & - \\
\hline $\begin{array}{l}\text { Faeoal } \\
\text { Calcium } \\
\text { (g/d) }\end{array}$ & $1.03^{\mathrm{d}}$ & $1.17^{d}$ & $1.53^{\mathrm{d}}$ & $2.05^{b c}$ & $2.82^{b c}$ & $3.42^{b c}$ & $4.15^{\mathrm{ab}}$ & 2.31 & \pm 0.07 \\
\hline $\begin{array}{l}\text { Urinary } \\
\text { calcium } \\
\text { (g/d) }\end{array}$ & $0.03^{d}$ & $0.04^{\mathrm{bc}}$ & $0.04^{b c}$ & $0.05^{b c}$ & $0.06^{\mathrm{ab}}$ & $0.07^{\mathrm{ab}}$ & $0.06^{\mathrm{ab}}$ & 0.05 & \pm 0.005 \\
\hline $\begin{array}{l}\text { True Ca } \\
\text { retention } \\
(\mathrm{g} / \mathrm{d})\end{array}$ & $0.85^{c}$ & $1.52^{\mathrm{cd}}$ & $2.10^{\mathrm{cd}}$ & $2.62^{b c}$ & $2.83^{b c}$ & $3.02^{\mathrm{ab}}$ & $3.40^{\mathrm{ab}}$ & 2.33 & \pm 0.06 \\
\hline $\begin{array}{l}\text { Availa- } \\
\text { bility } \\
(\%)\end{array}$ & $46.70^{b}$ & $57.57^{\mathrm{ab}}$ & $58.82^{\mathrm{ab}}$ & $57.0^{\mathrm{ab}}$ & $50.54^{\mathrm{b}}$ & $47.19^{b}$ & $45.3^{c}$ & 51.87 & \pm 3.08 \\
\hline
\end{tabular}

1 a,b,c,d,e Means on the same line with different superscripts differ significantly $(P<0.05)$. 
there seems no reason to believe that the faecal excretion of endogenous ca should be constant over varying ca intakes. This is because the bile secretions, digestive enzymes and the sloughed off portions of the intestinal mucosa, which are the major sources of endogenous ca, vary with dietary and physiological factors. it is recommended that in the absence of more critical studies on the endogenous loss of calcium in growing lambs in Nigeria, the value of $5.5 \mathrm{mg} / \mathrm{kg}$ body weight per day should be used as endogenous loss of ca for lambs below eight months of age and applied to conventional balance trials in arriving at the net calcium retention.

Hansard, et. al., (1957) reported availability of calcium carbonate for beef cattle as $50 \%$. Hodge (1973), with growing lambs weighing $18 \mathrm{~kg}$, showed that availability of ca in calcium carbonate was $51 \%$. The figure $(48 \%)$ obtained in this experiment for calcium carbonate used, compares with the values of Hansard, et. al., (1957) and Hodge (1973). Result of the growth studies (Table 2) showed that the overall performance of the lambs on treatments 4.5.6 and7 were similar as the difference were not significant. The relationship between the rate of gain and calcium retention was used in deriving the following equation:

$$
\mathrm{Y}=27.8+17.8 \times(\mathrm{r}=0.976)
$$

where

$X=$ calcium retention ( $g /$ day); and,

$\mathrm{Y}=\quad$ rate of gain $(\mathrm{g} /$ day $)$.

The average rate of gain for animals on treatments 4, 5, 6 and 7. was 77.85 groups. Applying this value in the equation above shows net calcium requirements of growing lambs in this experiment, as $2.8 \mathrm{gm}$ per day $(77.85-27.8+17.8 \mathrm{X})$. The availability of the calcium source used was $48 \%$ (Table 3 ). The mean initial and final live weights of the lambs was 19.02 gms. The dietary requirement for each lamb for calcium carbonate was therefore $5.8 \mathrm{gm}$ per day $(2.8 \times 100 \div$ 19.02). Although very wide range of value has been reported for temperate sheep in terms of their calcium requirement, $183 \mathrm{mg} / \mathrm{kg}$ body weight per day NRC, 1975; $250 \mathrm{mg} / \mathrm{kg}$ body weight Hodge, 1973, it is evident that the lambs in this region require more calcium in their diet than most temperate sheep. Reasons for this may include losses in sweat, which could be more appreciable at high temperatures, breed and species differences as well as the lower quality of feed intake, which would imply a greater intake to meet metabolic needs.

The result of the metabolism study (Table 3) showed that dry matter digestibility was markedly improved by calcium supplementation. 'According to Varner and woods (1972), calcium carbonate and corn starch singularly or in combination, significantly increased organic matter and cellulose digestion as compared to the basal ration. Their result confirmed earlier observations. (Burroughs, et al., 1950; Hubbert, et. al., 1958; and Davidson and Woods, 1961. Result of the present study is in agreement with these findings. It is evident therefore that the improved growth performance observed with increasing levels of dietary calcium, was a result of better utilization of the nutrients, achieved through mineral supplement. Studies (Field, et. al., 1975 Sykes and Dingwall 1976) had shown that energy digestibility and nitrogen utilization were improved by calcium and phosphorus supplementation.

Mineral requirement of farm livestock is generally expressed in terms of dietary concentration. The merits of this approach have been the case of ration formulation as well as greater uniformity achieved in mineral concentration in the diet. Many reasons can be adduced against this approach, the most potent being the availability factor. As 
pointed out (Hansard, et. al., 1954), availability of calcium and phosphorus from different sources may vary widely. Since this variation in availability will significantly influence the dietary requirement of the animal for the minerals, it is suggested that availability figure for each source of the element in a supplement, be included, to facilitate an appraisal of dietary levels.

\section{ACKNOWLEDGEMENT}

We wish to thank the Ahmadu Bello University Senate Board of Research for funding this project. We are also grateful to Mallam I. Lawal of the Soil Science Laboratory, Institute for Agricultural Research, Zaria for the biochemical analysis of the samples.

\section{REFERENCES}

ADEGBOLA, A.A. (1971): Livestock Production Problems Associated with Mineral Deficiencies or Excesses in West Africa with Special Emphasis on Nigeria. In Mineral Studies with Isotopes in Domestic Animals. Proc. of Panel organized by the Joint FAO/LAFA Div. of Atomic Energy in Food and Agriculture. Vienna.

A.O.A.C. (1980): Official Methods of Analysis (13 Ed.) Association of Official Analytical Chemists, Washington D.C.

BURROUGHS, W., FRANK, N.A., CERLAUGH, P. and BENTHKE, R.M. (1950): Preliminary Observations upon Factors Influencing Cellulose Digestion by Rumen Micro-organisms. $J$. Nutr., 40: 9-24.

DAVIDSON, K.L. and WOODS, W, (1961): Calcium and Corn Oil Interrelationships as Influencing Ration utilization by Lambs. J. Animal Sci., 20: 532.

FIELD, A.C., SUTTLE, N.F. and NISBET, D.I. (1975): Effects of Diets Low in Calcium and Phosphorus on the Development of Growing Lambs. $J$. Agric. Sci. (Camb), 85:435-442.
FISHE, C.H. and SUBBAROW, Y. (1925): The Colorimetric Determination of Phosphorus. J. Biol. Chem., 66: 375-400.

FOOD and AGRICULTURAL ORGANISATION (1966): Agricultural Development in Nigeria, 1966-1980. Chapter 13, Livestock Development, pp.214-215. F.A.O., Rome.

HANSARD, S.L., XOMAR, C.L. and PLUMES, M.P. (1954): The Effects of Age upon Calcium Utilization and Maintenance Requirements in the Bovine. J. Animal Sci., 13: 25-36.

HANSARD, S.L., CROWDER, H.M. and LYKE, W.A. (1957): The Biological Availability of Calcium in Feeds for Cattle. J. Animal Sci. 16: 437-443.

HAWK, P.B. OSER, B.L. and SUMMERSON, W.H. (1947): Practical Physiological Chemistry, 12th Ed.

Hodge, R.W. (1973): Calcium Requirement of the Young Lamb II: Estimation of Calcium Requirements by the Factorial Method. Austr. J. Agric. Res., 24: 237-243.

HUBBERT, F., CHENG. E. and BURROUGHS, W. (1958): Cited in Reactions in the Rumen (ed. A.J.C. Barnbett and R.L. Reid), Edward Arnold Publ. Ltd., London.

LANSBURY, J.T. (1960): A Review of some Limiting Factors in the Nutrition of Cattle on the Accra Plains, Ghana. Trop. Agric., 35 185-192.

LUCKER, J.B. and LOFGREEN, G.P. (1961): Effects of Intake and Calcium to Phosphorus Ratio on Absorption of these elements by sheep. J. Nutr. 74: 233-238.

MILLER, T.B. (1961): Studies on the Nutrition of Zebu Cattle in Northern Nigeria. Emp. J. Exp. Agric., 29: 230244.

NATIONAL RESEARCH COUNCIL (1975): Nutrient Requirement, No. 5, Nutrient Requirement of Sheep. 5th Revised Ed., 1975.

OYENUGA, V.A. 91958): Problems of Livestock Nutrition in Nigeria. Nutri. Abstr. Revs., 28: 985-1000.

SHAW, T. and COLVILLE, C. (1950): Report of the Nigerian Livestock Mission, .pp. 67-76, H.M.S.O., London. 
STEEL, R.C.D. and TORRIE, J .H. (1960): Principles and Froceatires of Statistics. McGraw-Hill Book Coy., New York.

SYKES, A.R. anর DYGWALL, F.A. (1976): The Phosphorus Requirement of Pregnant Sheep. J. Agric. Sci. (Camb), 86: 584-594.

TILLMAN, A.D. and BRETHOUR, J.R. (1958): The Effect of Cornoil upon the Metabolism of Calcium and Phosphorus by Sheep. J. Animal Sci. 17: 782-786.
VARNER, L.W. and WOODS, W. (1972): Effect of Calcium and Starch Addition upon Ration Digestibility by Steers. $J$. Animal; Sci. 35: 410-414.

WILLIS, J.B. (1960): Determination of Calcium in Blood Scrum by Atomic absorption Spectroscopy. Anal. Chemt, 33: $556-559$. 